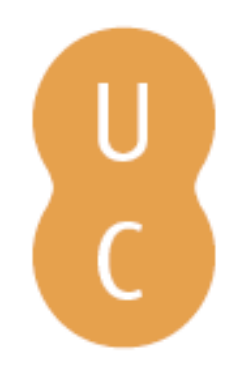

\title{
nommalina
}

\section{Effects of habitat loss waders (Aves, Charadrii) in the Mondego estuary: a synthesis and future perspectives}

Autor(es): $\quad$ Múrias, Tiago; Marques, João Carlos; Goss-Custard, John

Publicado por: Imprensa da Universidade de Coimbra

URL

persistente: URI:http://hdl.handle.net/10316.2/32729

DOI: $\quad$ DOI:http://dx.doi.org/10.14195/978-989-26-0336-0_34

Accessed : $\quad$ 26-Apr-2023 16:34:56

A navegação consulta e descarregamento dos títulos inseridos nas Bibliotecas Digitais UC Digitalis, UC Pombalina e UC Impactum, pressupõem a aceitação plena e sem reservas dos Termos e Condições de Uso destas Bibliotecas Digitais, disponíveis em https://digitalis.uc.pt/pt-pt/termos.

Conforme exposto nos referidos Termos e Condições de Uso, o descarregamento de títulos de acesso restrito requer uma licença válida de autorização devendo o utilizador aceder ao(s) documento(s) a partir de um endereço de IP da instituição detentora da supramencionada licença.

Ao utilizador é apenas permitido o descarregamento para uso pessoal, pelo que o emprego do(s) título(s) descarregado(s) para outro fim, designadamente comercial, carece de autorização do respetivo autor ou editor da obra.

Na medida em que todas as obras da UC Digitalis se encontram protegidas pelo Código do Direito de Autor e Direitos Conexos e demais legislação aplicável, toda a cópia, parcial ou total, deste documento, nos casos em que é legalmente admitida, deverá conter ou fazer-se acompanhar por este aviso.

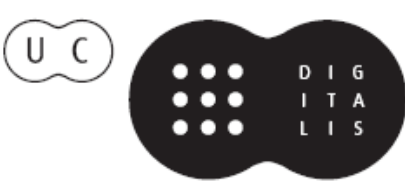


MIGUEL ÂNGELO PARDAL JOÄO CARLOS MARQUES MANUEL AUGUSTO GRAÇA Scientific Editors

\section{Aquatic Ecology of the Mondego River Basin Global Importance of Local Experience}




\author{
MIGUEL ÂNGELO PARDAL \\ JOẢO CARLOS MARQUES \\ MANUEL AUGUSTO GRAÇA \\ Scientific Editors
}

\title{
Aquatic Ecology of the Mondego River Basin Global Importance of Local Experience
}




COORDENAÇÃO EDITORIAL
Imprensa da Universidade de Coimbra
CONCEPÇÃO GRAFICA
António Barros
INFOGRAFIA
António Resende
Estimulus [design] • Coimbra
EXECUÇÃO GRAFICA
GRAFIASA
ILUSTRAÇÃO DA CAPA
P. P. Cunha e ]. Dinis
ISBN
972-8704-04-6
DEPOSITO LEGAL
I75038/02

(C) JANEIRO 2002, IMPRENSA DA UnIVERSIDADE DE COIMBRA

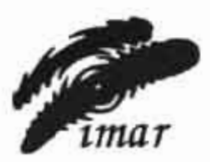

CPIMAR

imar

OBRA PUBLICADA COM O PATROCINIO DE:

IMAR - INSTITUTO DO MAR

IPIMAR - INSTITUTO DE INVESTIGAÇĀO DAS PESCAS E DO MAR 



\title{
TIAGO MÚRIAS ' \\ João Carlos Marques ' \\ JOHN GOSS-CUSTARD ${ }^{2}$
}

\section{EFFECTS OF HABITAT LOSS ON WADERS (AVES, CHARADRII) IN THE MONDEGO ESTUARY: A SYNTHESIS AND FUTURE PERSPECTIVES}

\begin{abstract}
The destruction of the salines represents one of the major threats to the wader populations in the Mondego estuary (Portugal). Although the actual levels of competition in the intertidal habitats are low, thus allowing for many displaced birds from the salines to settle there, these birds will still lose part of their previous feeding space and time. The ongoing eutrophication process in the estuary will further aggravate this. The conservation of this area. in what the wader populations are concerned, demands an integrated policy of all authorities and individuals involved.
\end{abstract}

\section{Introduction}

Habitat loss is probably the most intensively examined of the factors that are known to potentially affect the survival of estuarine wader populations (Goss-Custard et al. 1996a, b). Most studied cases have focused on the consequences for waders of the direct loss of intertidal low-water feeding areas through land reclamation for industrial, agricultural or water storage purposes (Davidson et al. 1991), and of indirect losses due to the submersion of previously accessible feeding areas following the construction of tidal power and storm-surge barriers or sea-walls, as a consequence of a sea-level raise (Meire et al. 1994. Lambeck et al. 1996). In contrast, there have been few studies dealing with the consequences of the loss of supratidal feeding areas, probably because in north European estuaries these are not heavily used, or critically endangered, although their importance for waders is recognised (Davidson and Evans 1986. Hötker 1994)

The situation may be different in the south European Atlantic estuaries. Supratidal habitats, such as the salines, usually occupy large areas within the estuaries and "nas".

(i) IMAR - Instituto do Mar. Centro Interdisciplinar de Coimbra a/c. Departamento de Zoologia, Universidade de Coimbra. 3004-517 Coimbra, Portugal

(2) Centre for Ecology and Hydrology (CEH) - Dorset. Dorset DT2 8ZD. United Kingdom 
and seem to be intensively used throughout the tidal cycle, by a lot of species (Rufino et al. 1984, Perez-Hurtado et al. 1991, 1993b). These man-made wetlands are currently more threatened in the southern European estuaries than are the natural intertidal areas, mainly due to their abandonment and/or transformation into fish-farms or rice fields (Rufino and Neves 1992, Neves and Rufino 1995, Perez-Hurtado and Hortas 1993a).

The loss of salines would affect the two broad groups of birds that use them in slightly different ways. One group of waders feed over the low-water period on the intertidal mudflats. If these birds are, however, unable to obtain all they require, they then feed in the salines over high tide when their preferred intertidal flats are no longer available. These birds were called the "intertidal birds". The other group of birds is those which feed in the salines throughout the tidal cycle, both at low and high water, and rarely if ever utilise the mudflats of the intertidal area. These were called the "salines birds" (Múrias 1997).

The removal of the salines would remove all the feeding space presently used by the "salines birds". which would thus lose all the current feeding time, as well. Those birds would probably try to settle in the mudflats (Meire et al. 1994, Lambeck et al, 1996). Their survival in the estuary would then depend on their actual feeding requirements in the salines (i.e. if they are able to get all the food they need within the 8.5 hour limit for feeding at low-water in the mudflats), and of the present level of competition in the intertidal areas (Goss-Custard and West 1997).

The "intertidal birds", on the other hand, would lose the extra feeding time they presently use at high-water, when their main feeding areas in the intertidal mudflats are unavailable. On many occasions, particularly in the more energetically-demanding periods of the year, these birds will not be able to recover this feeding time by extending their foraging at low-water through an increase in the foraging time and/or in the intake rate (Davidson and Evans 1986. Goss-Custard et al. 1996c). Their only chance, if they were to remain on the area would be, therefore, to look for altemative supratidal sites.

The present paper summarises the results of a research study conducted on the problem and potential consequences for waders of habitat loss in the estuary of Mondego, in 1993-95 (Múrias 1997). Three main issues were examined in this study of the potential effects of habitat loss on waders in the Mondego estuary: a) the importance of the salines as feeding habitats; b) the ability of the mudflats to support the displaced birds in case the salines were destroyed, and c) the effects on all this, of

516 the increasing eutrophication process which is actually taking place in the Mondego estuary.

\section{Study Area and Methods}

The Mondego is a warm-temperate estuary in a region with a basic Mediterranean climate. The terminal part of the estuary consists of two arms, north and south, that surround an alluvion-formed island, the Morracerra (Figure I). Due to 
distinct hydrodynamics in the two arms, the south arm is heavily silted-up, thus providing the most important intertidal areas (134 ha) which, along with the salines of the Morraceira Island, are the most suitable feeding areas for waders in the estuary. There is a north-south gradient of increasingly finer sediments in this arm (Marques et al. 1993). In late spring and summer of some years, the finer sediments are covered with extensive weed mats. which remain in place until the beginning of the winter (Múrias 1997). For the purpose of this study, the intertidal area was subdivided in three naturally delimited sub-areas, of 66.8 ha (upstream section), 30.9 ha (middle section) and 36.1 ha (downstream section).

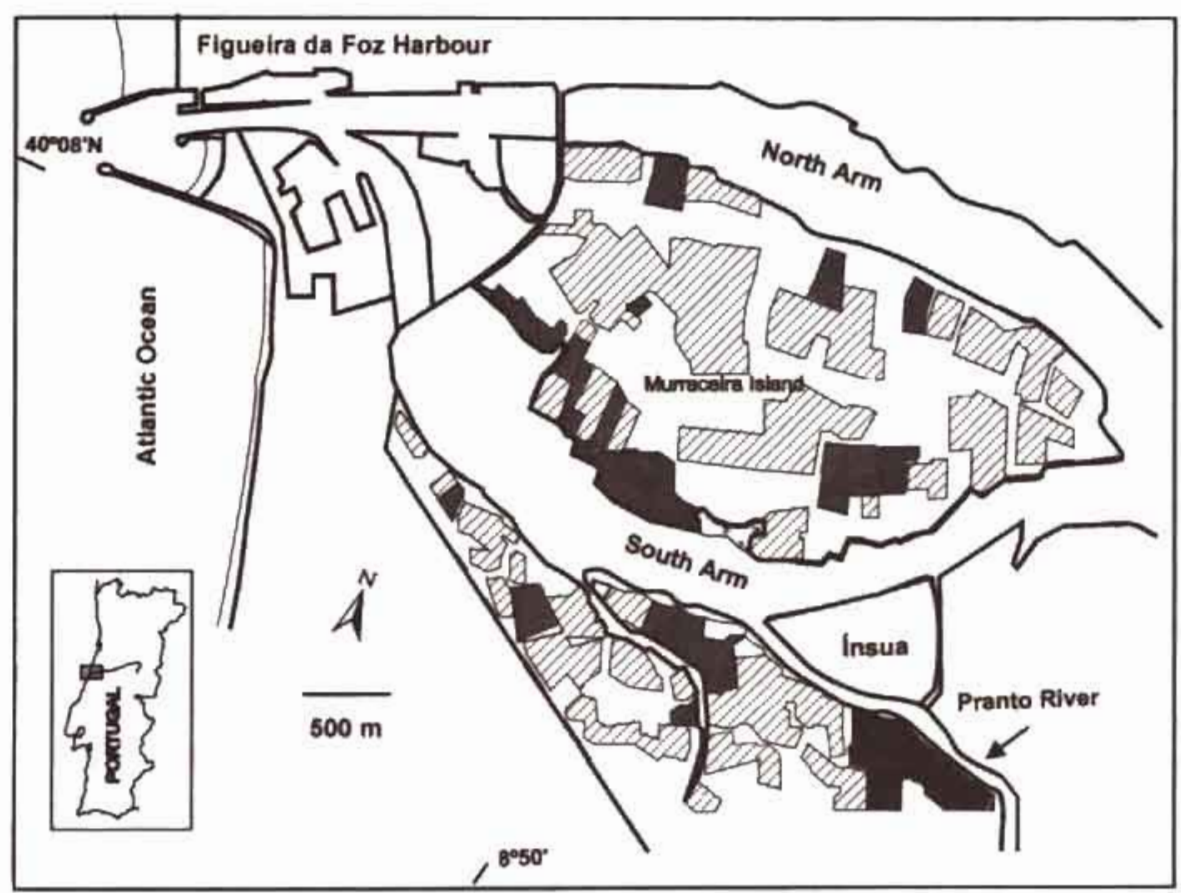

Fig. 1. The estuary of Mondego showing the location of the main area of artisanal salines (stuppled). fishfarms (dark-grey) and industral salines (black). The abanndoned salines of the north amm and the Insua are not represented. The main intertidal areas are located along the south arm

The basic method used to estimate bird numbers were high water and low-water censuses, carried out with $10 \times 50$ binoculars and a 20-60 $\times 50$ telescope, in the Morraceira's salines and in three fixed plots along the south arm of the estuary. The counts were performed each month, from October 1993 to January 1994 and fortnightly onwards, to May 1995. 
Invertebrate samples were taken along fixed transects in the south arm with a corer, $95 \mathrm{~cm}^{2}, 5 \mathrm{~cm}$ deep, taken to the laboratory and sorted, identified, counted and measured according to the usual procedures (Marques et al. 1993a, Múrias 1997. Múrias et al. 2002).

A more detailed account of the methods used can be found in Múrias et al. (1996) and Múrias (1997).

\section{Results and Discussion}

\section{Loss of salines}

Overall, the results of this study suggest that, due to time loss, many birds in this estuary could be in trouble were all the salines to be destroyed.

The salines were shown to be intensively used by most wader species at highwater, both as complementary feeding areas to the main feeding places in the intertidal mudflats, but also at low-water, as alternative feeding areas, with a high proportion feeding there at all times (Table 1). However, the number of salines available to the waders in the estuary is rapidly decreasing, due to abandonment and transformation of the ponds into fish farms (Table 2).

Table I. Percentage of the total number of birds of each species counted in the whole study area at low-water (N) that used the Morraceira's salinas at low and high-water (in parenthesis, percentage of birds that were feeding). Values represent the average number of birds present per count in the estuary over the whole study period (October 1994 to May 1995, maximum $n=38$ counts).

\begin{tabular}{|c|c|c|c|c|c|c|}
\hline \multirow[b]{2}{*}{ Black-winged Stit Himantopus himantopus } & \multirow{2}{*}{$\begin{array}{c}N \pm S E \\
624 \pm 9.9\end{array}$} & \multirow{2}{*}{$\begin{array}{l}(n) \\
(22)\end{array}$} & \multicolumn{2}{|c|}{$\begin{array}{c}\text { Low-water } \\
\%\end{array}$} & \multicolumn{2}{|c|}{$\begin{array}{c}\text { High-water } \\
\%\end{array}$} \\
\hline & & & 79.7 & $(68.9)$ & 87.4 & $(70.0)$ \\
\hline Redshank Tringo totanus & $124 \pm 3.7$ & (26) & 53.3 & $(65.0)$ & 69.0 & $(67,4)$ \\
\hline Little Stint Colidris minuto & $25.3 \pm 11.1$ & (21) & 52.9 & $(59.3)$ & 77.4 & (59.3) \\
\hline Dunlin Colidris alpina & $451.6 \pm 74.4$ & (37) & 20.0 & $(70.1)$ & 60.0 & (70.2) \\
\hline Kentish Plover Choradrius olexandrinus & $91.5 \pm 10.6$ & (38) & 18.8 & $(48.3)$ & 59.4 & $(42.4)$ \\
\hline Ringed Plover Charodrius hiaticula & $66.7 \pm 11.3$ & (34) & 121 & (61.5) & 57.7 & $(50.7)$ \\
\hline Whimbrel Numenius phoeopus & $7.9 \pm 3.4$ & (7) & 6.9 & $(5.0)$ & 255 & (36) \\
\hline Grey Plover Pluviolis squotarola & $86.6 \pm 10.8$ & (2B) & 13 & (3.8) & 4.3 & (8.4) \\
\hline Avocet Recurvirostro avosetto & $388.6 \pm 53.4$ & (18) & $<0.1$ & $(0.5)$ & 0.1 & (3.7) \\
\hline
\end{tabular}

Note: Only the species with 5 birds per season and per year, or more, were considered 
Table 2. The loss of salines by abandonment and transformation into fish-farms in the Morraceira Isiand up until 1994. Total number of salines in the Morracerra before 1984 was 229. with an area of 305.1 ha. These figures do not include some salines levelled prior to 1984.

\begin{tabular}{lccc}
\hline & $1955-1984$ & $1984-1994$ & Total \\
\hline Number of salines abandoned & 2.6 & 30 & 56 \\
Number of salinas transformed & - & 22 & 22 \\
Total number lost & 26 & 52 & 78 \\
$\%$ of total number lost & $11.4^{\prime}$ & 25.6 & 34.0 \\
Rate of loss (salines.year') & 0.9 & 5.2 & 1.9 \\
Area abandoned (ha) & 35.3 & 51.0 & 86.3 \\
Area transformed (ha) & 35.3 & 19.7 & 19.7 \\
Total area lost (ha) & $11.6^{1}$ & 70.7 & 106.0 \\
\% of total area lost & 1.2 & 7.2 & 34.7 \\
Rate of loss (area.year') & & & 2.5 \\
\hline
\end{tabular}

' Calculated in each period by excluding the total number already lost in the preceding period(s).

' Calculated in each period by excluding the total area already lost in the preceding penod(s).

'The number of years is: pre-1984 - 30 years; $1984-94$ - 10 years.

Ultimately, this process may force these birds to leave the salines and try to reestablish themselves on the mudflats, if they are still able to accommodate them.

All depends on the present-day level of competition in the mudflats and how close the densities of the birds are, in these areas, to reach the point where their mortality rates, or body condition, become density-dependent. As stressed by GossCustard and West (1997), the moment were this point is reached is what really matters to this issue, as it ultimately leads to a reduction in local bird numbers, through intensified competition, well before the carrying capacity is reached, if ever.

At the moment, all data seems to suggest that the effects of competition on the mudflats, either through interference or through resource depletion, are weak (Figure 2). Therefore, a number of the birds that use the salines as alternative feeding areas to the mudflats could eventually re-establish themselves in the intertidal flats at low-water. buffering the loss of low-tide feeding space in the salines. However, even these birds seemed to intensively use the salines for feeding at high-water (Table 1). So, the need for finding supplementary supratidal feeding areas could involve both groups of birds. the mudflat-feeders and the salines-feeders.

The problem arises because no other supratidal habitat in the estuary is likely to offer the good feeding conditions that birds can presently find in the salines. The rice fields are only usable at certain times of the year, at other times being too flooded (in winter) or too dry (in summer). Furthermone, it is unlikely that birds that do not feed on mudflats covered by algae the "bare-sediment" specialists, such as the small plovers (Kentish and Ringed Plovers) would use this habitat at all. Elsewhere, saltmarshes are also commonly used supplementary feeding sites for mudflat feeders, both in Europe 


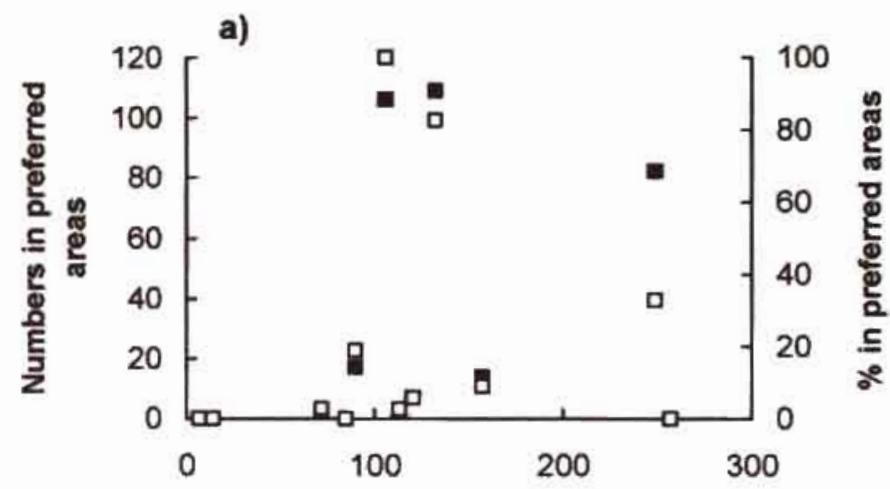

Total numbers in the estuary

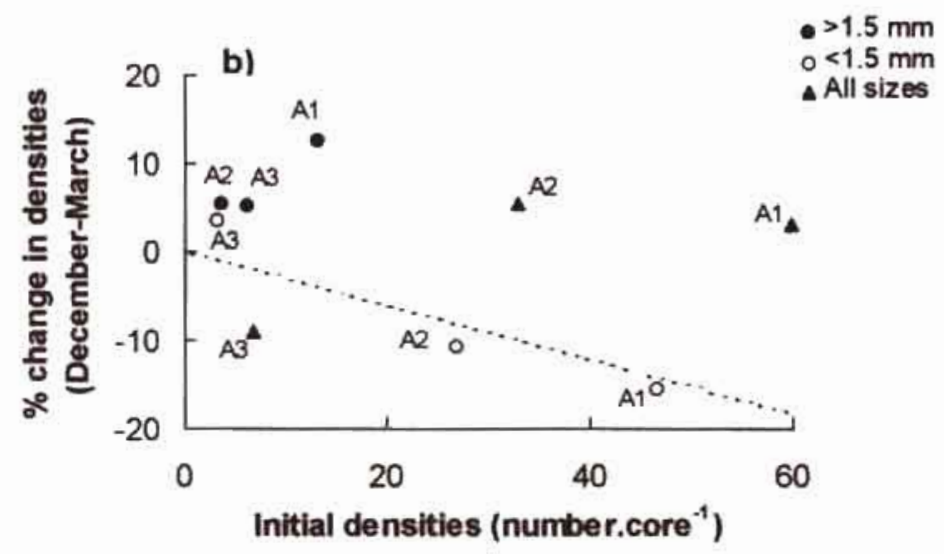

Fig. 2. Graphics showing the absence of competition by (a) interference of feeding birds and (b) resource depletion, In (a) it is illustrated the evolution in bird numbers (E) and in the percentage of these birds in preferred areas $(\square)$ for Ringed Plover Charodrius haticula. The preferred areas are defined as being those areas firstly occupied by birds (Goss-Custard, 1980) in case interference competition was operating, the number of birds in preferred areas should initially increase and then, with the increase in total numbers in the estuary, reach a plateau, indicating that these areas were already full. The percentage of birds in preferred areas, on the contrary, should follow the opposite trends, as more and more birds were driven out from the preferred areas by competition and forced to establish in poorer areas. In (b) is investigated whether the depletion of Hydrobio ulvoe populations by birds in the estuary during the mnter (November-March) was density-dependent (indicated by the dotted line). thus suggesting that the competition for food was high (birds tend to concentrate where the densities of their prey are higher). No such trend was found for the class of prey consumed by the birds (> $1.5 \mathrm{~mm}$ ), therefore suggesting that no significant depletion occurred during the study penod.

and in South Africa (Davidson and Evans 1986. Velasquez et al. 1990, Velasquez and Hockey (991). However, in the Mondego, they are mainly formed by Spartina sp., whose dense stands are known to deter many small species, such as Dunlin (GossCustard and Moser 1988). Only the langer species (Grey Plover. Whimbrel, godwits) were occasionally seen using this habitat in the Mondego, but these would probably be the least affected species by the loss of the salines (see Tables I and 3). 
Table 3. The calculated amount of feeding space (expressed as the percentage of "bind feedinghours", or BFH - number of feeding birds $\times$ number of hours spent feeding) and feeding time lost by several wader species in the estuary of Mondego in case the salines are destroyed, and the predicted increase in the feeding pressure on the mudflats if all birds displaced from the salines try to settle there. Two groups of birds with slightly different strategies were considered: thase that used the salines as altemative feeding to the mudflats, throughout the tidal cycle (the "salines birds"), and those that used the salines only at high-water, as supplementary feeding areas to the intertidal mudflats (the "mudflat birds"). Values are means for 1993.94 and 1994-95, averaged for auturnn, winter and spring, therefore, $N=6$ for all species, except for Whimbrel, for which $N=2$. and Avocet, for which $\mathrm{N}=5$.

\begin{tabular}{|c|c|c|c|c|c|}
\hline & \multirow{2}{*}{$\begin{array}{l}\text { Total feeding } \\
(B F H \pm 15 E)\end{array}$} & \multirow{2}{*}{$\begin{array}{c}\text { 'Mudflat' } \\
\text { Space } \\
\text { loss (\%) }\end{array}$} & \multirow{2}{*}{$\begin{array}{c}\text { birds } \\
\text { Space } \\
\text { loss' }(\%)\end{array}$} & \multirow{2}{*}{$\begin{array}{c}\text { Salinas" brords } \\
\text { Space } \\
\text { loss' (\%) }\end{array}$} & \multirow{2}{*}{$\begin{array}{c}\text { Predicted } \\
\text { increase in } \mathrm{BF}- \\
\text { in the mudflats } \\
\text { (in } \% \text { ) }\end{array}$} \\
\hline & & & & & \\
\hline Redstrank & $199.9 \pm 772$ & 70.0 & 25.0 & 36.9 & 66.0 \\
\hline Little Sunt & $3340 \pm 154.3$ & 68.0 & - & 185 & 900 \\
\hline Dunin & $2318.1 \pm 1780.7$ & 237 & 375 & 16.7 & 42.6 \\
\hline Kentish Plover & $668.6 \pm 71.4$ & 221 & 9.4 & 165 & 348 \\
\hline Runged Plover & $610.6 \pm 211$ & 9.8 & 163 & 20.7 & 26.9 \\
\hline Grey Plover & $449.4 \pm 622$ & 35 & 132 & $\cdot \cdot$ & 45 \\
\hline Avocet & $1256.0 \pm 392.2$ & 0.5 & & 0.1 & 1.1 \\
\hline Whimbrel & $569 \pm 67$ & 00 & & $\therefore$ & os \\
\hline All species & $736.9 \pm 272.3$ & 24.7 & 20.3 & 15.5 & 33.3 \\
\hline
\end{tabular}

'BFH in the mudflats at low.water + salines at both high and low. water

'Calculated as the percentage of feeding time above the 8 hours avalable for feeding in the mudflats that is currently used by the mudflat bards in the salines at high-water. Maxomum feeding time was assumed to be 12.5 hous each tidal cycle. and total feeding tome per species were Redshank - 10 hours. Little Stin - 4.4 hours; Dunin - 11.0 hours; K. Plover . 8.8 hours, R. Plover - 9.3 hours G. Plover - 91 hours ; Avocet - 55 hours Whimbrel - 78 hours

'Equvalent to the same amount of tme lons, as these birds are assumed to feed in the salinas throughout the tidal cyde ' Less than $0.1 \%$

A less suitable but still usable alternative supratidal site to the salines could be provided by the fish-farms. They have the advantage of being encircled by wire fences, thus providing quiet and relatively safe places from attack by raptors. In fact, waders use them now as roosting sites. However, the ponds are usually too deep for waders to feed there even for the long-legged species, and in practice they are used only when they are periodically emptied for cleaning (Perez-Hurtado and Hortas, 1993a, b). In the Mondego, even this periodic usage seems to be infrequent (at least it was never observed during the present study), probably due to the depth and to the narrow dimensions of the ponds.

\section{Blooms of algae}

Loss of intertidal habitat could also occur in the estuary, through the increasingly extensive "blooms" of green macroalgae that occur seasonally due to eutrophication (Marques et al. 1993a, b). The presence of contiguous and extensive algae mats would be expected to decrease the abundance of many prey species (see, e.g. Everett 1994), 
and the subsequent recolonisation after the algal crash. from the small islets of unweeded areas that would remain, would be insufficient to replace the losses (Raffaelli et al. 1989, 1991). Waders could then be unable to find enough food to meet their daily requirements in the previously weeded areas.

In fact, although the effects of the eutrophication at the low levels of the trophic chain can be assessed in a matter of 2-3 years (e.g. Soulsby et al. 1982, Desprez et al. 1992. Everett 1994). its consequences for waders may take more time to be established. Subtle changes in the diet of some waders, when the populations of their main prey are affected, usually appear even before any change in numbers begin to be noted (Desprez et al. 1992). Only in a later stage of the process do waders respond by changing their feeding areas. In the Mondego, no indication was obtained that the waders changed feeding areas due to the presence of algae (see Múrias et al. Chopter 5.2 of this book). On the contrary, although circumstantial, there was evidence that some species (e.g Dunlin) could even be attracted to the mats during, or soon after. the algal "bloom". had taken place in early spring.

Apart for some methodological reasons and the time-scale used (Múrias et al. Chapter 5.2 of this book), another factor may account for the lack of a relationship between bird numbers and algae in the Mondego. The prey most consumed by waders in this estuary seem to be mobile sediment-water interface feeders, such as some errant polychaetes and Hydrobia ulvoe (Lopes et al. 1998), which may be favoured, at least in the earlier stages of the season, by the growth of algae (Soulsby et al. 1982, Everett 1994), thus providing enhanced, even though seasonally-limited, food resources for the waders.

Implications for the management of the system

In summary, this study suggested that the main threat to estuarine waders in the Mondego at present is the continuing destruction of the supratidal habitats. It seems that there is some buffering capacity on the mudflats to recerve a number of displaced birds from the salinas. However, the lack of sufficient area in the supratidal habitats themselves that would enable birds to recover the feeding time that would be lost with the loss of the salines, could be detrimental to the populations of many species. In the long-term, the effects of the loss of supratidal habitat could be further aggravated if the eutrophication continues to increase at the present rate, thereby perhaps also reducing the available feeding space for waders at low-water, if the

522 growth was severe enough.

From a conservation point of view. there is always the possibility of creating artificial supratidal habitats to replace those that are lost (Davidson and Evans 1986. 1987. Hötker 1994). There are, however, some limitations on the creation of adequate artificial supratidal wetiands. These are (i) the large areas that are required to allow for the settlement of all the displaced birds; (ii) the need to provide similar habitats to those destroyed, particularly in terms of their sediment types and invertebrate faunas, in order to attract the same species that were displaced; and (iii) the need to begin the work some years (2-3) in advance of the destruction of the primary habitat. due to 
the time required to find an appropriate place, prepare the area and allow the settlement and growth of the invertebrate prey (Davidson and Evans 1987). Even so, there is no absolute assurance that waders will accept the new sites. Hötker (1994) showed that at least two of three artificially-created supratidal habitats in the German and Danish part of the Wadden Sea, that were constructed to compensate for the loss of reclaimed intertidal habitats, did contribute to the increase the number of bird species and densities in the area, but they did not fully compensate the losses due to land claims.

It seems that prevention is still the best way to avoid the more deleterious effects of habitat loss. In the Mondego, there may still be time to reverse the present trend. Many salines have been abandoned, but not yet transformed. Deserted salines are not completely unattractive to waders (Múrias et al. submitted), although they are far less used than the active ones. An effective and relatively inexpensive way of recovering these salines for waders would be to pay their owners to keep them clean and to maintain a permanently controlled water level. This would avoid the salines conversion or dranage. An alternative or, even better, complementary solution would be to impose strict rules on the construction of new fish farms in the estuary, by improving the design of the pond walls, in order to create areas of shallow water, as it was suggested by Rehfisch (1994) for man-made brackish lagoons in England. This could allow even the smaller waders to use the ponds, although some care should be taken to prevent the access of piscivourous birds (e.g. herons).

Regarding eutrophication, any local intervention (e.g. by imposing some form of treatment of the urban, agriculture and fish-farm discharges to the estuary) would not be enough. It would be also necessary to control the urban and agncultural discharges along the whole lower river valley, in which the majority of rice fields and other extensively irrigated lands are located. This is a very difficult task, however, as it requires the involvement of many different official and private organisations.

Besides the obvious need to preserve the estuarine biodiversity and the health of the whole ecosystem, of which waders are an important component, there is another important reason why the quality of the habitat for waders should be maintained or even enhanced in this estuary. Small estuaries like the Mondego, with relatively low number of waders, as compared to the major estuaries of the East Atlantic Flyway (Smit and Piersma 1989), may act as "emergency" sites for some migrating or wintering birds. Emergency sites are areas where, in normal conditions, few birds land. but where, under adverse weather, they may stage in great numbers (Piersma, 1987 in Smit and Piersma 1989). This may prevent many birds from starving, avoiding the high mortality rates which otherwise would probably occur. Moreover, the real number of birds of all species that use the estuary of Mondego may have been underestimated, particularly during the migratory periods. As Smit and Piersma (1989) showed for a small Moroccan estuary (Sidi Moussa), the spring migration peak of 7000 birds underestimated by 3 times the real number of individual birds that crossed the area during a two-month period, as investigated by an intensive counting (3-5 days counts) and colour-marking program. If this is also the case in the Mondego, its perceived importance for waders would naturally increase still further. 


\section{Acnowledgements}

This work was supported by the Portuguese Research Board (JNICT), through grants FMRH/BD/331/93 and PRAXIS XXV/BD/5570/95 (TM). The authors are also indebted to all the colleagues that helped in the fieldwork, and to an anonymous referee for the constructive comments.

\section{References}

Davidson N.C. and Evans PR 1986. The role and potential of man-made and man-modified wetlands in the enhancement of the survival of overwintering shoreburds. Colonial Waterbirds $9(2): 176-188$.

Davidson N.C. and Evans P.R 1987. Habitat reconstruction and creaton: its role and potential in the conservation of waders in The Conservation of International Flyway Populations of Waders (Davidson N.C. and Pienikowskl MW. eds). Wader Study Group 49/RWB Special Publication 7. pp. 139-145.

Dandson NC.. Laffoley D d'A. Doody J.P. Way LS. Gordon I. Key R. Pienkowsk M.W. Mitctiell R. and Duff K. 1991. Nature Conservation and Estuaries in Great Britain. Nature Conservation Councl. Petersborough.

Desprez R. Rybarczyk H. Wilson J,G. Ducrotoy P. Sueur F. Olivesı R and Elkaim B. 1992 Biological impact of eutrophication in the Bay of Somme and the induction and impact of anoxia. Neth. Sea Res. 30: 149. 159

Everett R.A. 1994. Macroalgae in manne soft-sediment communities: effects on benthic faunal assemblages. 1. Exp. Mar. Brol. Ecol. 175: 253-274

Goss-Custard J.D. and Moser M.E. 1988. Rates of change in the numbers of Dunlin Caldris alping wintering in British estuaries in relation to the spread of Spartina onglica. Joum. Appl. Ecol. 25: 95-109.

Goss-Custard J.D and West A.O 1997. The concept of carrying capacity and shorebirds in Effect of habitat loss and change on waterbirds (Goss-Custard JD. Rufino R and Luis A. eds.) TTE Symposium 30/Wetlands intemational Publication 42. London,

Goss-Custard I.D. Dureil S.E.A. le V. dit. Clarke R. T. Benterna AJ.. Caldow RWG. Meinunger P.L and Smit C.J. 1996a. Polulation dynamics predicting the consequences of habitat change at the continental scale in The Oystercatcher. From indinduals to populations (Goss-Custard J.D. ed). pp. 352-381. Oxford Universitiy Press. Oxford.

Goss-Custard J.D., West, A.D., Clarke R.T., Caldow RW.G. and Durell S.E.A. le V. din 1996b. The carrynng capacity of coastal habitats for Oystercatchers. In The Oystercatcher From individuals to populations (Goss-Custand J.D., ed.). pp. 327-351. Oxford Universitry Press, Oxford.

Goss-Custard I.D. West, A.D. Clarke R.T, Caldow RW.G and Durell S.EA, le V dit 1996c. How Oystercatchers survive the winter. In The Oystercatcher. From individuals to populations (Goss-Custard I.D. ed.). pp. 133.154. Oxford University Press. Oxford.

Hötker H. 1994. Wadden Sea birds and embankments - can artificial wetlands compensate for losses due to land diams? Ophelia Suppl. 6: 279-295.

Lambeck RH. Goss-Custand J.D. and Triplet P. 1996. Oystercatchers and the man in the coastal zone In The Oystercatcher. From individuals to populations (Goss-Custard J.D. ed). pp. 289-326. Oxiond University Press. Oxford

524 Lopes R. Cabral J.. Múnas T. and Marques JC. 1998. Contribuição para o conhecimerto da dieta do Pilritocomum Colidris alpina e da Tarambola-cinzenta Pluviolis squatarola no estuảno do Mondega. Auro $9(1 / 2)$ : 28-33.

Marques J.C. Rodrigues L.S.B and Nogueira A.J.A. 1993a Intertudal macrobenthic communities structure in the Mondego estuary (Westem Portugal). reference situation. Vie Milieu $43 \quad 177.187$

Marques J.C. Maranhão P. and Pardal M.A. 1993b. Human impact assessment on the subtidal macrobenthic community structure in the Mondego estuary (Western Portugai). Estuar. Coast Shelf Scl 37:403-419

Mere P.M, Schekkman H. and Meininger P. 1994. Consumption of benthic invertebrates by waterbirds in the Oosterschelde estuary. SW Netherlands. Hydrobiologia 282/283: 52S-546.

Múnas T. 1997. Effects of habitat loss on waders (Aves, Charadrii) in the Mondego estuary (Portugal). PhD Thesis. University of Coimbra Coimbra. 
Múrias T. Cabral, JA. Marques JC. and Goss-Custard J.D. 1996. Short-term effects of intertudal macroalgae blooms on the microhabitat selection and leeding behavour of wading birds in the Mondego estuary (West Portugaly. Estuar: Coast. Shelf Sci 43:677-688

Múrias T., Cabral JA. Lopes R. and Carlos Marques J.C. 2002 Effects of eutrophication on waders (Aves: Charadrii) in the Mondego estuary: a multi-level aproach (Chapter of this book)

Neves R and Rufino R 1995 importância omitológica das salinas: o caso particular do estuáno do Sado. Estudos de Biologia e Conservaçāo da Natureza 15. ICN. Lisboa.

Perez-Hurtado A and Hortas F, 1991 . Information about the use of the salines and fish-ponds by winterng waders in Cadiz Bay, southwest Span Wader Study Group Bull, 66: 48-53.

Perez-Hurtado A and Hortas F. 1993a. Actrvidad tofica de limicolas inveranates en salinas $Y$ cultivos piscicolas de la Bahia de Cadiz Doñana, Acta Vert 20 (2) $103-123$.

Perez-Hurtado A and Hortas F 19936 importancia de la Bahia de Cadiz para las poblaciones de limicolas invernantes e influencia de las transformaciones humanas Ardeola 40 (2): $133-142$

Raffaelli D.G. Hull S.C. and Mine H 1989. Long-term changes in nutrients, weed mats and shorebirds in an estuarne system Cah. Bich. Mar. 30: 258-270.

Raffaelli J.D. Limia J. Hull S. and Pont S. 1991 interaction between the amphipod Corophum volutator and macroalgal mats on estuarne mudflats. . Mar Biol. Assoc. UK. 71: 899-908.

Rufino $R$ and Neves R 1992. The effect on wader populations of the convertion of salinas into fistifarms IWRB specal Publication 20: 177-182.

Rufino R. Araujio A. Pina J,P, and Miranda PS. 1984. The use of salinas by waders in Algarve. South Portugal Wader Study Group Bull. 42:41-42.

Rehfisch M. 1994 Man-made lagoons and how their attractiveness to waders might be increased by manipulating bromass of an insect benthos f. Appl. Ecol. 31: 383.401 .

Soulsby P.G. Lowthion D. and Houston M. 1982 Effects of macroalgal mats on the ecology of intertidal mudflats, Mar. Pollut. Bull. 13:162-166.

Smit J.C. and Piersma T. 1989 . Numbers, midwinter distribution, and migration of wader populations using the East Atlantic flyway In Flyways and Reserve Networks for Watertirds (Boyd $\mathrm{H}$, and Pirot J.H., eds.). IWRB Special Publication 9, pp. 24-63.

Velasquez C.P. and Hockey PA.R 1990. Seasonal abundance. habitat selection and energy consumption of waterbirds at the Berg River estuary, South Afnca. Ostnch 62: 109-123.

Velasquez C.P. and Hockey PA.R. 1991. The importance of supratidal foraging habitats for waders in a south temperate estuary. Ardea 80: 243.253. 
Série

Investigação

$\bullet$

Coimbra

Imprensa da Universidade

2002 